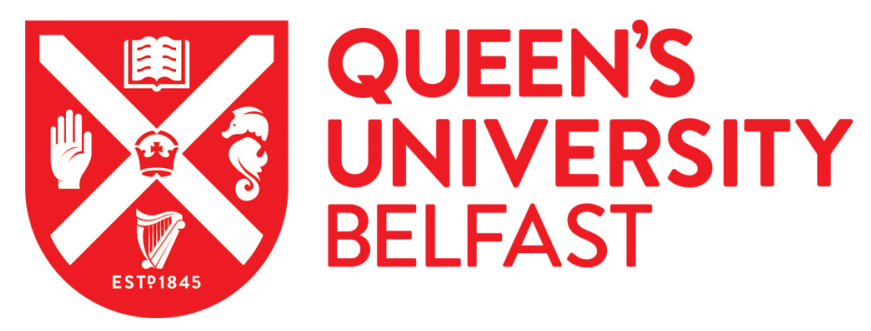

\title{
Where Is This Story Going? A Critical Analysis of the Emerging Field of Narrative Criminology
}

Maruna, S., \& Liem, M. (2020). Where Is This Story Going? A Critical Analysis of the Emerging Field of Narrative Criminology. Annual Review of Criminology, 4, 125. https://doi.org/10.1146/annurev-criminol-061020-021757

Published in:

Annual Review of Criminology

Document Version:

Peer reviewed version

Queen's University Belfast - Research Portal:

Link to publication record in Queen's University Belfast Research Portal

Publisher rights

Copyright 2020 Annual Reviews. This work is made available online in accordance with the publisher's policies. Please refer to any applicable terms of use of the publisher.

\section{General rights}

Copyright for the publications made accessible via the Queen's University Belfast Research Portal is retained by the author(s) and / or other copyright owners and it is a condition of accessing these publications that users recognise and abide by the legal requirements associated with these rights.

Take down policy

The Research Portal is Queen's institutional repository that provides access to Queen's research output. Every effort has been made to ensure that content in the Research Portal does not infringe any person's rights, or applicable UK laws. If you discover content in the Research Portal that you believe breaches copyright or violates any law, please contact openaccess@qub.ac.uk. 


\title{
Where is this Story Going?:
}

\section{A Critical Analysis of the Emerging Field of Narrative Criminology}

\author{
Shadd Maruna \\ Queen's University Belfast \\ s.maruna@qub.ac.uk \\ ORCID: 0000-0002-4978-7073 \\ Marieke Liem \\ Leiden University \\ m.c.a.liem@fgga.leidenuniv.nl \\ ORCID: 0000-0002-2653-4356
}

\begin{abstract}
:
Over the past decade, a growing body of literature has emerged under the umbrella of narrative criminology. We trace the origins of this field to narrative scholarship in the social sciences more broadly, and review the recent history of criminological engagement in this field. We then review contemporary developments, paying particular attention to research around desistance and victimology. Our review highlights the most important critiques and challenges for narrative criminology, and suggests fruitful directions in moving forward. We conclude by making a case for the consolidation and integration of narrative criminology, in hopes that this movement becomes more than an isolated clique.
\end{abstract}

Keywords: Narrative Criminology, Narrative Identity Theory, Life History Interviewing, Neutralization Techniques 


\section{Introduction}

"[Survivors of abuse] are eager to tell their narratives, and they ask me to 'take their stories' - for telling them validates a life, names the abuse, honors the escape" (Lawless, 2001, p. 3).

"I'm not saying I didn't do this offence. Pretty much mine and my victim's story are aligned with each other. ... My problem is with the wording that my probation officer is using" (A person in prison interviewed by Ievins, 2019, p. 289).

"[T] he idea there are two sides to every story is wrong. There are really six or seven sides! ... I sort of suspend my belief and that allows me to not take a side, to not get too focused on one avenue versus another" (Restorative justice mediator quoted in Katz, Bascombe and Tokar, 2019, p. 355).

Criminology continues to disagree on the best way to define this thing we call 'crime' with many in the field uncomfortable using a definition that is dependent upon state authority (Michalowski, 2016). One definition that has received relatively little attention in these debates is that, in an important respect, a crime is a "story" (Dollinger, 2020). After all, crimes involve physical actions, of course, but these actions are morally neutral processes that only become criminal when the events are imbued with meaning via a narrative. Such a definition would not be controversial to journalists or writers of fiction. Writers know that almost nothing makes as good a story as a crime (Sparks, 1992). Moreover, practitioners in the criminal justice field are themselves expert at the collecting and analyzing of stories. Police officers, for instance, almost never witness serious crimes in real time whilst patrolling a neighborhood; instead, they rely on witness and victim accounts to piece together what happened and to discern whether these stories indeed constitute a crime. Courts and probation officers likewise take additional statements, comparing these stories to the accounts of others. The criminal trial (when it occurs) is a competition of opposing narratives. Rehabilitation work in prisons and probation largely involves challenging the stories of those who have been convicted in therapeutic encounters (Stevens, 2012). Finally, the person who leaves the correctional process with the label of "former prisoner" is then asked to account for what he or she did dozens or indeed hundreds of times to parole authorities, prospective employers, partners, family members, friends or acquaintances (see Liem, 2017; Maruna, 2001). Everyone wants to know "the story."

Considering this relationship between stories and crime, one might expect that the science of criminology would be focused on the analysis of storytelling and the tools of narratology, with criminology students trained in understanding how stories are constructed and their impact on human lives. Indeed, a movement is underway in criminology internationally under the banner of "narrative criminology" (Presser, 2009) that seeks to foreground the study of story in just this way. Narrative criminology has been variously defined as "Any inquiry based on the view of stories as instigating, sustaining, or effecting desistance from harmful action" (Presser \& Sandberg, 2015, p. 1) or more generally as "the study of the relationship between narratives and harmful actions and patterns" (Presser, 2018, p. 2). Although narrative criminology contains elements of method and theory, narrative criminology is neither a particular methodology nor a specific theory of crime. Primarily, narrative criminology represents a clarion call for criminology to take stories seriously in our study of human lives. 
In this review, we seek to heed this important call. After defining some key terms, we provide a brief overview of narrative scholarship in the social sciences more broadly, then trace the history of criminological engagement on this topic prior to Presser's coining the term "narrative criminology" in 2009. Next, we review contemporary developments in the field, focusing in particular on two well-developed areas of research around desistance and victimology. Finally, we engage with the primary critiques and challenges for narrative criminology, suggesting ways forward. We conclude with a plea for the mainstreaming of narrative criminology, so this important trend does not become another insular clique in a field at risk of splitting into isolated factions.

\section{What is Narrative Criminology?}

Before proceeding, some key terms need to be defined, beginning with the concept of "narrative" itself. As Ryan (2007, p. 22) writes: "Few words have enjoyed so much use and suffered so much abuse as narrative." Indeed, currently there is no agreed definition of narrative (Avdi \& Georgaca, 2007). Critics like Rudrum (2006) even argue that that the "very idea" of defining a story is an impossibility, comparing it to Augustine's effort to explain what time is. Although we tend to know one when we hear one, even expert narratologists struggle to put into words just what constitutes a narrative.

Almost every attempt at a definition agrees that a narrative is a subjective, temporal representation of an event or series of events (see Ricoeur, 1994). Yet, temporality is not enough. A model rocket instruction manual, a "to do" list, or a soufflé recipe might be a temporally ordered sequence of events, but these are not typically understood as stories. Stories are also imbued with intentionality and purpose. Narrative is the way that human beings make sense out of human (or human-like) lives and make them meaningful and understandable (Bruner, 1986).

In our review, we will use the terms "narrative" and "story" interchangeably. We are not, however, equating "narrative" with "discourse" or with broader constructs. Narrative is certainly a type of discourse, but not all discourse takes the shape of a narrative (Foucault, 1972). Nor is narrative synonymous with language or verbal communication. In fact, narratives need not be language-based at all. The earliest stories were carved into cave walls by early humans in depictions of hunts and heroism, and narrative criminologists have similarly explored the "stories in images" (Copes, Hochstetler \& Ragland, 2019) in efforts to "read pictures" (Carrabine, 2019) for their implicit narrative content. So what makes some forms of communication into a story? Consider the famous six-word short story, attributed to Hemingway (but see Wright, 2014): "For sale: baby shoes, never worn." This is a great story. With hardly any words, it conveys a tragic sequence of events with a powerful message about the precarity of life. As Copeland (2019) argues, stories can communicate a great deal by what is unsaid or not fully told. Yet, remove the words "never worn" from that sentence and it is no longer a story. It is communication, it is discourse, but there is no story to be analyzed, no plot, no theme, no moral to the story.

We will occasionally use the term "self-narrative" to refer to a psychological construct taking the form of an internalized autobiography or self-understanding (see Narrative in Social Inquiry, below). These internal stories are thought to represent the person's self-identity, a core aspect of personality, providing "modern life with some modicum of psychosocial unity 
and purpose" (McAdams, 2001 p. 101). These "stories we live by" (McAdams, 1993) are not the same thing as the narratives that are told in a therapeutic encounter, in front of a parole board, or even in a research interview. Yet, McAdams (1993, p. 20) argues that these verbal accounts "hold the outlines of internalized personal myths." That is, the best way to get access to an internal self-narrative is to listen to the external narratives the narrator routinely tells about him or herself.

Finally, narrative criminology should be distinguished from the more general, umbrella category of qualitative criminology to which it belongs. The field of criminology has a long history of utilizing autobiographical narratives of individuals in the justice system dating back over 100 years (see Bennett, 1981, for a comprehensive history). Yet, relatively little of this qualitative criminology would qualify as being "narrative criminology." Although classic studies like Sutherland's (1937) The Professional Thief or Shaw's (1930) The Jack-Roller utilize stories as data to illustrate or illuminate theory, they focus on the factual content of the stories, not the subjectivity of the storytelling itself. For instance, Shaw (1930) made "no attempt to pursue the implications of the Jack-Roller's idiosyncratic point of view for an understanding of his involvement in delinquent conduct" (Finestone, 1976, p. 10). ${ }^{1}$ Like much contemporary work using qualitative data (see e.g., Cromwell 1998; Sampson \& Laub 1993 ) this work treats narratives as a means of learning about individuals histories, not their self-understandings.

By contrast, narrative criminology asks what stories $d o$ for their tellers and for their listeners, why some stories are told and others untold, and how this telling impacts patterns of crime and justice (Maruna \& Matravers, 2007). Because narrative criminology is "attentive primarily to people's stories and not the events purportedly behind stories" (Sandberg, 2010, p. 13), it "matters little" whether the content of the stories is 'true' or 'false' (Presser, 2016, p. 139; see also Wickramagamage \& Miller, 2019). The core idea of narrative criminology is that stories not only help make sense of lives, but that stories themselves, when internalized by human actors, make "criminologically relevant things happen," and more broadly, "shape the morally significant things that we do" (Presser, 2016 pp. 139-140). The story becomes interesting therefore not because of what truths it can tell us about a person's past but rather what it might say about the person's future.

\section{Narrative in Social Inquiry}

The understanding of human beings as fundamentally "storytelling animals" (or what Ferrand \& Weil 2001 label "homo narrativus") dates back at least to Aristotle's Poetics (see Sandberg \& Ugelvik, 2016). This view, however, has gained considerable attention in what is sometimes referred to as the "Narrative Turn" in the social sciences more generally -- one of the primary challenges to $20^{\text {th }}$ Century positivist conceptions of social science (Brown, Nolan, Crawford \& Lewis, 1994; Maines, 1993). With increasing interest from philosophy, psychology, sociology, political science, anthropology, social work, education, communication studies, as well as more distal fields like artificial intelligence and jurisprudence, narrative research does not belong to any one discipline. Indeed, the philosopher David Carr (1991, p. 160) argues that narrative studies have been "a meeting ground and battle ground of the disciplines." Narrative criminology, however, has been most

\footnotetext{
${ }^{1}$ For a distinctly narrative criminological re-analysis of the Jack-Roller data, see e.g., Gadd \& Jefferson, 2007; Gelsthorpe, 2007; Koesling \& Neuber, 2007.
} 
heavily influenced by two particular strands of narrative inquiry - studies of identity and culture, both of which are thought to have a distinctly narrative nature.

Narrative identity theory is best associated with the field of personality psychology (McAdams, 1993), yet the theory transcends psychology with groundbreaking contributions in sociology (e.g., Giddens, 1991; Holstein \& Gubrium, 2000) and philosophy (e.g., Ricoeur, 1994; Taylor, 1989), and applications ranging from marketing (Elliott and

Wattanasuwan ,1998) to midwifery (Divall 2015). Indeed, three decades ago, one of the pioneers of narrative identity theory, John Kotre (1984, p. 265), argued that although psychology is the "natural home" of research on self-narratives, the field had been "the most stubborn about granting it legitimacy anywhere but in the clinic." From its origins, psychology has sought to establish itself as a "real" science, aligned to medicine rather than the humanities, and "serious scientists did not concern themselves with fantasies, stories, and myths" since these sorts of narratives seemed "too soft... [and] too singular" to be proper data for an emerging science (McAdams, 2001, p. 100). This was soon to change dramatically when a wave of psychological research on narrative beginning in the late 1980s led Sarbin (1986) to argue that narrative should become the "root metaphor" for psychology itself. Most prominently, the pioneering cognitive psychologist Jerome Bruner (1986) brought considerable legitimacy to the field in his work on "narrative ways of knowing." Developing an argument originally put forward by William James (1893), Bruner (1986) contrasted "paradigmatic" (logical, scientific) reasoning with "narrative" reasoning, and argued that humans use the latter in order to connect actions to intentionality and human agency, imbuing our life experiences with meaning and purpose.

Narrative identity theory posits that self-identity (the human being's answer to the question "who am I?") is itself an internalized narrative integrating the person's past history, present circumstances and future plans into a coherent account (Habermas \& Bluck, 2000; McAdams, 1993). This evolving life story is a central aspect of human personality, drawing on culturally meaningful stories to provide the construction of the self with a sense of personal continuity and coherence. Giddens (1991, p. 54) writes: "A person's identity is not to be found in behavior, nor - important though this is - in the reactions of others, but in the capacity to keep a particular narrative going" (p. 54). Through narrative identity, "people convey to themselves and to others who they are now, how they came to be, and where they think their lives may be going in the future. In other words, understanding the person is understanding his or her story" (McAdams \& McLean, 2013).

Story's role as a means of discerning meaning and purpose out of the chaos of life seems to be no small thing. Gottschall $(2012$, p. 1) even argues that storytelling is what "makes us human." However, narrative theorists have gone even further by suggesting that selfnarratives also can organize experience, shape emotion and (crucially) enable and guide action (Sarbin, 1986). Bruner (1987, p. 15) argues that, "In the end, we become the autobiographical narratives by which we 'tell about' our lives" (italics in original). This aspect of stories makes them particularly intriguing for criminologists focused less on meaning-making than on behavior. Kruttschnitt and Kang (2019, p. 3) write:

Individuals act according to their narrative identities because, as McNay (1999) explains, "it would violate their sense of being to do otherwise" (p. 318). Thus, studying the narratives of prisoners is critical for understanding the pathways to offending, the prospects of reentry, and the likelihood of desistance from crime. 
Almost every form of psychotherapy is premised on some version of this theory - to change entrenched patterns of behavior, you need to change your story - but none more so than what is called "narrative therapy" (White, 2007). Narrative therapy seeks to first "download" clients' internalized self-stories through dialogue about the person's understanding of her past, present and future. In later sessions, clients are encouraged to "deconstruct" and "reauthor" their stories by "examining the meaning behind certain narratives and to create new narratives that attribute different meanings to experiences within the broader context of their lives" (Ermann, Lawson, \& Burge 2017, p. 14).

These agentic aspects of narrative identity theory are balanced by an equal influence from cultural sociology that recognizes the shared and collective aspect of narratives. According to Loseke (2007), narrative identity occurs at three levels: micro-level (personal identities), meso-level (institutional and organizational identities), and macro-level (cultural identities). All three levels are intimately connected as micro-level life stories are thought to "mirror the culture wherein the story is made and told" (McAdams, 2001, p. 114). Cultural sociology's interest in narratives essentially begins with these higher levels of influence on personal narratives. As Sandberg and Ugelvik (2016, p. 130) write: "We are not just passive consumers of stories; we interact with them and they act on us." In this framework, culture itself, understood as a shared interpretive system, consists largely of shared collective stories or "meta-narratives" (see Saleebey, 1994).

Cultural anthropology has recognized the central place of folk tales, legends, myths and parables in the shaping of what we call culture since the origins of that field (Geertz, 1973), but this understanding extends to numerous fields. The philosopher Jean-Paul Sartre $(1938 / 1965$, p. 61) argued that "man lives surrounded by his stories and the stories of others, he sees everything that happens to him through them." The evolutionary biologist E. O. Wilson makes a similar case that the human mind "is a narrative machine," and that those stories that "prove most innately satisfying spread and become culture" (Wilson, 2005, ix). Feminist and intersectional scholars have similarly recognized the power inherent in the stories that are told in a culture. As Laird (1989, p.440) writes: "As more and more women tell their own stories and as stories are told about women in biography, novel, play, and poem and in music, film, television, and radio, women's choices for self-construction are enriched and expanded. Women ... discover new possibilities for their lives.”

Perhaps the most famous (or infamous) meta-narrative is the widely shared cultural myth of the "American Dream." Lamont (2019) has recently argued that the American Dream's emphasis on material prosperity as a core indicator of human achievement and virtue has profoundly shaped (indeed warped) the political and policy landscape of American society. Of course, the influence of this story on the identity work and behavioral adaptations of Americans has been explored in criminology since Merton's (1938) pioneering work on the role of strain in criminal etiology (see Messner \& Rosenfeld, 2012).

\section{The Pre-History of Narrative Criminology}

Clearly, then, the impact of stories on deviant and criminal behavior has deep roots in criminology. Although the label "narrative criminology" was only created a decade ago (Presser, 2009; Sandberg, 2010), some of the earliest known works of criminology, by authors like Henry Mayhew and John Clay, drew extensively on stories in seeking to understand the roots of criminal behavior (Bennett, 1981; Dollinger, 2018). As Scott and 
Lyman (1968, p. 62) point out, "Since it is with respect to deviant behavior that we call for accounts, the study of deviance and the study of accounts are intrinsically related, and a clarification of accounts will constitute a clarification of deviant phenomena."

Work in the symbolic interactionist tradition, guided by the mantra "If [people] define situations as real, they are real in their consequences" has long linked deviant behavior to the ways that individuals interpret the world. Indeed, in the original passage containing that famous phrase, itself, was actually a discussion of a prisoner who had wrongly imagined that his victims had been mocking him behind his back (Thomas and Thomas, 1928, p. 572). The criminological pioneer Donald Cressey became interested in first-person accounts following his research on in his study of the rationalizations of embezzlers (Cressey, 1953). Cressey (1963) argued that "Criminals and delinquents become dishonest because of the words available to them" (Cressey, 1963, p. 151). Likewise, Redl and Wineman (1951, p. 147) outline a series of ego defense mechanisms (or "guilt evasion tricks") employed by young people in trouble with the law: "He did it first;" "Everybody else does such things anyway;" "We were all in on it," "He had it coming to him" (p. 147).

Gresham Sykes and David Matza (1957) drew on both of these traditions in what has become the best known and most influential precursor to narrative criminology, their theory of "neutralization techniques" (see Maruna \& Copes, 2005). The heart of this argument is that the excuses and justifications that deviants use to rationalize their behaviors might themselves be implicated in the etiology of deviant behavior. They argue that neutralization techniques "precede deviant behavior and make deviant behavior possible" (p. 666); therefore, "It is by learning these techniques that the juvenile becomes delinquent" (p. 667). Crucially, Sykes and Matza argue that all of these neutralizations are "extensions of patterns of thought prevalent in society rather than something created de novo" (p. 669). The legacy of neutralization theory has been decidedly mixed. On the one hand, six decades later the theory remains the subject of numerous studies and analyses, almost all of which confirm that deviants of almost every stripe habitually utilize neutralization techniques in their post-hoc explanations for their actions. On the other hand, research has largely stopped at coding these techniques, or identifying new ones, in personal accounts without developing the theory into a more comprehensive theory of self-narratives (see Maruna \& Copes, 2005; 2016).

The cognate literature on addiction and substance abuse has arguably developed a much more sophisticated narrative theory of the role of self-narratives in maintaining addictive behavior patterns or abstinence from substance use (Singer, 1997), not least because of the substantial role that storytelling plays within recovery communities like Alcoholics Anonymous and Narcotics Anonymous (O'Reilly, 1997). Researchers like Biernacki (1986) argue that "addict identities" can prolong addiction problems and the process of recovery involves the development of alternative stories of the self (see Best, Irving \& Albertson, 2017; Kay \& Monaghan, 2019).

\section{Contemporary Developments in Narrative Criminology}

Considering all of these important precursors and all of the activity around narrative theory in related disciplines over the past forty years, criminology has undoubtedly been "late to the party" in terms of developing its own narrative "turn" (Pemberton, Mulder \& Aarten, 2019, p. 392). Yet, beginning in the first decade of the $21^{\text {st }}$ Century, a purposeful and self-aware narrative criminology emerged for the first time, drawing both on precursors in criminology 
like neutralization theory and the wide range of resource material outside criminology (see esp. Presser \& Sandberg, 2015). New research has explored the role of narratives on a wide variety of criminological topics ranging from political extremism to "bad trips" experienced by drug users (see Fleetwood, Presser, Sandberg \& Ugelvik, 2019). Most of this work is only beginning to develop, and is probably too early to review, but at least two topics (desistance narratives and victimization stories) have matured into full-blown bodies of criminological research already.

\section{Narratives and Desistance}

The study of desistance from crime is unquestionably the area in which narrative criminology has had the most sustained development (Harding et al., 2017). Partially, this is because this work had an earlier onset, with self-narratives first appearing, albeit in different guises, in pioneering work by Sampson and Laub (1993), Maruna (1997; 2001), Giordano and colleagues (2002), and Paternoster and Bushway (2009, see esp. Bachman et al., 2016). With well over 100 studies employing an explicitly narrative approach to desistance now published, ${ }^{2}$ there is now enough research to assess the viability of narrative criminology going forward, including on other research topics.

Desistance research seeks to understand how and why individuals who had formerly been involved in criminal behavior are able to abstain from such involvement in the future. Some argue that this process involves the creation of a coherent and sustainable narrative that explains why someone had previously been involved in criminality but is now no longer at risk for doing so (Maruna, 1997, 2001). Such narratives are thought to be important for both social and psychological reasons. People who have been criminalized, punished and stigmatized are considered to pose a threat for potential employers, landlords, partners or friends (Stone, 2015). Desistance narratives can play a crucial remedial function by portraying them in a sympathetic and empowering light in their efforts to integrate into society and accrue the forms of social capital that all of us need in order to survive (Leverentz, 2014). Indeed, the social pressures for creating and presenting such a narrative begin even earlier with a person's release from prison and correctional supervision often dependent upon their ability to convince others of the legitimacy of their reform (Harding et al., 2017; Soyer, 2014). At the same time, an internalized desistance narrative is thought to play an important psychological function. A strong identity narrative can help people maintain their efforts to desist in the face of the hurdles, frustrations, disappointments and temptations they will inevitably face in their efforts to reintegrate (Vaughan, 2007).

Maruna (2001) found that in a sample of ex-prisoners in Liverpool, UK, there were discernible patterns among the self-narratives of successfully desisting individuals (which he labelled a "redemption script") that differed from the narratives told by a matched sample of former prisoners who were persisting in criminal behavior in the community (which he labelled a "condemnation script"). Desistance narratives in the study began by establishing the narrator's "good core self" and tend to explain past offending behavior as being the product of forces outside of the narrator's control (peer pressure, abusive pasts, lack of opportunity). Although active offenders also used a variety of neutralization techniques to explain why they were condemned or "doomed" to criminality, desisting narratives included

\footnotetext{
${ }^{2}$ As an indication of this scale, a Google Scholar search (29 Feb 2020) on " "self-narrative' and desistance" returns 480 results; “"redemption script' and desistance" returns 307; and, "'narrative identity' and desistance" returns 479. For reviews of this work, see O'Sullivan, Kemp \& Bright (2015); Rocque (2017); Sundt (2010); Veysey, Martinez and Christian (2013).
} 
a shift in agency or self-efficacy whereby the person had now managed to take control of his or her life circumstances, rather than be a victim of them. Finally, redemption scripts in the sample were characterized by a desire to give something back, to prove the person's worth to his or her community or family, and to assume positions of leadership as a parent, volunteer or helping professional.

Elements of this "redemption script" have been identified in dozens of subsequent studies across a wide variety of samples in the UK, the US, and beyond (see e.g., Appleton, 2010; Aresti et al., 2010; Kruttschnitt \& Kang, 2019; Stone 2016; Stone et al., 2018). At the same time, identity narratives are cultural products that are influenced by meta-narratives ranging from popular culture to religious traditions (see Blagden, Winder \& Lievesley 2020). So it is no surprise that research suggests that elements of successful desistance narratives will differ based on cultural, historical and demographic differences (e.g., Cid \& Martí, 2016).

Subsequent research has identified a range of variations to Maruna's original redemption script formula from an intersectional perspective (Fader \& Traylor, 2015), with a particular focus on gender differences in desistance narratives (Barr, 2019; Osterman, 2017), including the role of motherhood (Sharpe, 2015) and hegemonic masculinity (e.g., Carlsson 2013; Søgaard et al., 2016). Recent studies have also found fascinating differences in the narratives of those formerly involved in political violence or terrorism (van der Heide \& Hurrman, 2016), sex crimes (Harris, 2014) and intimate partner violence (Giordano et al., 2015); as well as those with diverse religious belief systems (Hallett \& McCoy, 2015; RobinsonEdwards \& Pinkney, 2018).

The voluntary process of "giving witness" in the form of telling one's story of recovery or redemption publicly is itself thought to have both psychosocial benefits (see Bullock, Bunce $\&$ McCarthy, 2019) as well as socio-political power as an organizing tool. For instance, the founder of the ex-prisoner-led activist organization Just Leadership USA argues that the stories of members are among the most effective means of changing public opinion:

We use that narrative to discuss the system, telling the truth about race and class discrimination in a way that helps people see how the reality of criminal justice does not match up to their ideas about either justice or fairness. People respond to anecdotes. You may forget data but you don't forget stories (Bader, 2015, p. 1).

Indeed, current desistance research has benefited enormously from the engagement of authors who themselves have lived experience of desistance (e.g., Hart \& Healy 2018; Weaver \& Weaver 2013) including the movement around "convict criminology" (e.g., Aresti et al., 2010).

At the same time, there are clear limitations set on the social availability of positive life scripts for those who have been criminalized that need to be recognized. Borrowing from cultural sociology, this body of research recognizes that self-narratives are "co-authored" in interactions, ranging from therapeutic encounters (Mullins \& Kirkwood, 2020; Stevens, 2012) to restorative justice mediation (Pelikan \& Hofinger, 2016). Mentors and mutual aid groups can provide "narrative maps" (Flores, 2016) and "memorable messages" (Stone 2019) that become instrumental in the development of one's own internal narrative (Harding et al., 2017; Weaver \& McNeill, 2015). Some forms of this narrative co-production -- including creative engagement with writing and other art forms inside prisons or treatment programs -simply encourage individuals to explore the stories they live by without imposing limits on new expressions of the self (see Albertson, 2015; Colvin, 2015; DeValiant, McGrath, \& 
Kougiali, 2020). In other circumstances, the co-production process can be more coercive, including the pressures placed upon individuals to adopt "self-blame" narratives (Denver \& Ewald, 2018) in therapeutic, court or parole settings (see Fox, 1999; Harding et al., 2017).

In a recent study of life sentenced prisoners, Warr (2019) terms this process "narrative labor". For lifers, he argues, more so than other prisoners, internal change is not enough. They must convince others that they have made fundamental changes to their identity, to navigate the day-to-day life in prison and eventually, secure release via the parole process. In essence, Warr (2019) holds, they must "cast themselves as the penitent and perform a flagellant self for those who make decisions about their carceral future. If they do not, then they do not progress through the prison made and do not secure release" (p.9).

Unsurprisingly then, research has shown that both incarcerated and non-incarcerated lifers alike present a prototypical reform story, rather than only those who considered themselves as desisting (Liem, 2016; Liem \& Richardson, 2014). At the time of the interview, many years after they were arrested, the large majority of interviewed lifers expressed that they were now different from the person they were at the time of the homicide, all subscribed to conventional moral values, and almost all emphasized that they had redeemed themselves and were now the person they were always meant to be. Most lifers discarded their past identity in favor of an alternative, pro-social one, and used generative motivations, ranging from speaking in public, running in-prison programs, and expressing a desire to give back. This narrative was not necessarily fake, in the sense that interviewees pretended to be something they were not, but rather a reflection of how they wished to present themselves vis à vis the parole board or other authorities (Liem, 2016; Liem \& Richardson, 2014). This finding is not unique, and has been encountered in other lifer populations (Herbert, 2018), which can partly be traced back to the role of lifers groups in prison, whose members help one another prepare for parole board hearings.

\section{Victim and Survivor Narratives: The Other Side of the Story}

Perhaps the most important area of growth for narrative criminology, in an era of \#Blacklivesmatter, \#MeToo and related momentums, is the emergence of a narrative victimology that appreciates the diverse role for narrative in the process of surviving serious harms (Hourigan, 2019). In the event of severe victimization, individuals' life stories are thrown into turmoil (Pemberton et al., 2018). Victimization may disrupt a person's self- or world-view, and survivors may struggle to understand their lives preceding the victimization event as being continuous with the present, the event itself, or the future. Also known as a "narrative rupture" (Pemberton \& Aarten 2018, p. 544), the victimization experience may threaten the sense of self-continuity, and may be accompanied with the feeling of "being out of sync with the rest of society" (Pemberton \& Aarten, 2018, p. 545).

Survivor narratives may play an agentic role in solving this conundrum, as such stories can act as vehicles for coming to terms with the way in which the past, the victimization experience, the present, and the future can be reconstructed to form a continuous and coherent whole. Victims may thus repair the "narrative rupture" in their life story by the creation and presentation of a victimization narrative, which enables them to retain "a sense of continuity in a temporal and interpersonal sense, is an important element of sense-and meaning making in the aftermath of victimization" (Pemberton et al., 2019, p. 406). Similar to desistance narratives, these stories may have a key agentic purpose. Indeed, Meyer (2016) 
argues that survivor narratives share an almost identical shape and structure to the "redemption scripts" identified in desistance research.

Like desistance narratives, survivor narratives play a social as well as an individual function as is most obvious in the movement around Black Lives Matter and especially \#MeToo. Born on online social platforms, \#MeToo has become a remarkably swift solidarity-building movement that has changed public narratives about sexual harm. Survivors who had felt silenced or ignored have started to publicly tell their stories, find their voices, and project their 'false' shame back onto those who violated them. The \#MeToo movement can be understood, at its heart, as a shame management movement against victim blaming rather than simply a movement in favor of the shaming of victimizers. Indeed, \#MeToo has redistributed blame not just to specific perpetrators, but also towards justice systems, the military, schools, orphanages, churches and even the totality of society in an attempt to rewrite societal stories about rape, assault and sexuality (see Maruna \& Pali, 2020).

The agentic quality of both collective and individual victim narratives can also be observed in the area of legislative change. Stories told by individual victims have been used to provide a narrative not only for their individual victimization but to stand for all those victims who might have had similar victimization experiences (Walklate et al., 2019). In the Anglo-Saxon world, the increasing presence of legislation named after particular victims is illustrative of this process, such as Megan's Law in the United States, Sarah's Law in the United Kingdom and Byron's Law in Australia -- pieces of legislation that were implemented in response to highly emotive, violent individual homicide or sex offense cases. Walklate and colleagues (2019) have dubbed this effect the 'Batty effect', referring to a woman by the name of Rosie Batty, who used her narrative as a mother of a murdered son, Luke, by his father, to contribute to policy reforms in family violence. In the so-called Batty effect, as in other victimization narratives used to bring about change, the narrator succeeds in presenting the narrative as a symbol for a wider public concern and ultimately, influential enough in framing a policy agenda (Walklate et al., 2019). At the same time, such media narratives can lead to the demonization and stigmatization of groups as "folk devils" (Cohen, 1972). Those accused of sexual offences in particular have become constructed as being an alien species beyond redemption (Meyer, 2010).

Victimization narratives also play a central role in the study of political conflict, terrorism and transitional justice (Copeland, 2019; Pemberton \& Aarten, 2018; Presser, 2013). Collective victimization narratives, as Pemberton and Aarten (2018) point out, may provide a shared evaluation of the event itself, its causes and its meaning and the emotions that are appropriate in discussing this event. Such collective victimization narratives further serve to provide meaning to those who experience "a sense of alienation from the master-narrative of society" (p. 549). Here, the victimization experience, or the sense that only those with this experience "can fully comprehend what the individual is going through and in tandem the distance from the narratives the culture supplies, forms the point of departure for the construction of a group-based community narrative" ( $\mathrm{p}, 550)$. Taken together, in prolonged conflict between politically motivated groups, either side has reason to see the other as an offender rather than as a victim: tales of suffering are contrasted to the suffering endured by one's own in-group and the violent action presented as retribution (Pemberton \& Aarten, 2018). From such victimization tales, combined with a sense of alienation, may spring legitimization for retributive violence in the shape of terrorism and other types of political violence. 


\section{Challenges Facing Narrative Criminology: A Critical Analysis}

Narrative criminology is now well enough established that critical analyses of the work have started to emerge, as is essential to the development of any field of work. In this section, we review some of the most important, lingering challenges facing narrative criminology. In particular, questions have been raised about how an internal self-narrative can be reliably accessed and measured, especially if they are "moving targets" (Brookman, 2015). Some have asked, just whose story is this? If narratives are co-created through dialogue with others, does the audience for the narrative distort the nature and content of the story through the process of co-creation? Perhaps narratives are simply post-hoc rationalizations that cannot be trusted as accurate accounts of history? Finally, others ask whether self-narratives have a causal explanatory function -- that is, do the narratives actually do anything? All of these questions are intertwined and overlapping, but taken together they express the primary concerns that many in criminology would have about narrative research.

\section{Can We Access and Measure Self-Narratives?}

Narrative criminology faces a core challenge of just how researchers can reliably access a self-narrative that is thought to be an "internal" construct. After all, the self-narrative is not the same thing as the narrative that a research participant tells a researcher in the context of an interview. Yet, this does not mean that spoken narratives are irrelevant or unrelated to the stories we "live by" according to theorists like McAdams:

I know that not everything people tell me is important, and that some of what they say may function merely to make them 'look good' in my eyes. I also know that there is much that will remain untold, no matter how successful our interview and how intimate our rapport. But an individual does not suddenly invent a personal myth in the course of an interview. The myth is there all along, inside the mind. It is a psychological structure that evolves slowly over time, infusing life with meaning and purpose. An interview can elicit aspects of that myth, offering me hints concerning the truth already in place in the mind of the teller (McAdams 1993, p. 20; emphasis added).

In this sense, narrative identity is no different than countless other social science constructs (from "intelligence" to "low self-control") that can only ever be imperfectly operationalized for research purposes.

Questions remain, however, about the best methodology for accessing these glimpses into a person's inner narrative(s). The most traditional and often-used method is likely the one-onone, confidential interview, audio-recorded, in privacy with promises of anonymity. Many studies have employed Interpretive Phenomenological Analysis (see e.g., Aresti, Eatough \& Brooks-Gordon, 2010), which involves methods for both data collection and analysis. Other research has benefited from utilizing semi-structured interviewing protocols such as the Life History Calendar (LHC), the Life Story Interview (LSI) or Life as a Film (LAAF). The Life History Calendar (LHC) presents a chronological and linear list of life events, that can be used as a tool to reflect the timing and sequencing of life transitions and the social contexts of these events. The LHC can be helpful in aiding in recall, particularly when gathering data on sensitive topics (Wittebrood \& Nieuwbeerta, 2000). Because of its visual design - which sets it apart from standard questionnaires - gaps in the life-course may easily be spotted, which 
can in turn be addressed interactively in the interview. McAdams' Life Story Interview (LSI) (1993) draws on the structure of a book, using a chapter-by-chapter structure, encouraging interviewees to reflect on key stages and transitions in their lives. The Life as a Film (LAAF) method (Canter and Youngs 2015) modifies this approach in a format that may be more relatable for interviewees who may struggle to think in terms of a novel, but can readily imagine their life on a screen. As Kang, Kruttschnitt \& Goodman (2017) have shown, the LAAF procedure can be used to compliment structured tools such as the LHC in that the LAAF allows respondents to more freely construct their own life story and mitigate the risks of capturing only well-rehearsed narratives co-created in therapeutic settings.

However, semi-structured interviewing is not the only or indeed the best way to access a person's self-narrative. Kirkwood (2015) has argued that identity narratives ought to be studied "in situ" to avoid decontextualizing identities (see also Pelikan \& Hofinger, 2016). To improve the "ecological validity" of narratives, he argues that these should be collected from other, more authentic interactions with the person's naturalistic social world. Some research seeks to do this by supplementing interviews with ethnographic observations (see Crewe \& Maruna, 2006) or through documentary analysis of other narratives of the self (diaries, letters, creative works). Beyond offering a form of data triangulation, these other exposures allow a more comprehensive and complete picture of an individual's identity in its social context.

At the same time, the problem with such rich and thick data is that it can be unwieldy in a research context even with advances in software for qualitative analysis. Even narrative research, then, often sacrifice richness of complicated qualitative data through data reduction and simplification to build larger, more manageable samples. For example, Maruna (2004) employed Content Analysis of Verbatim Explanations (CAVE) (Peterson, Schulman, Castellon, \& Seligman, 1992) to score narratives on themes like internal or external blame. Stone and colleagues (2018) quantitatively coded the use of redemption or contamination sequences in narratives of women ex-prisoners. Other researchers have taken this quantification a step further by seeking to develop survey questionnaires that can tap into elements of a person's self-narrative identified in qualitative research (see Johnson \& Maruna, 2020). Such mixed method developments make sense as strategies for expanding narrative insights to largescale research projects, although narrative criminologists warn that such efforts run the risk of over-simplification, reducing the complexity of human identities to stereotypical tropes and clichés (Sandberg, Tutenges \& Copes 2015).

\section{Are Narratives Stable Enough to Study?}

Unlike personality traits, which are theorized to be largely stable over time, narrative identity is thought to be evolving, dynamic, and (most importantly) responsive to changing life events (McAdams, 2001). Indeed, this aspect of self-narratives is what makes them so appealing for the study of long-term behavioral changes involved in desistance from crime (Hanninen and KoskiJannes, 1999; King, 2013). Nonetheless, this dynamic nature can also be problematic. If individuals are "constantly engaged in rewriting the self" (Harding et al., 2017), then perhaps narrative is too ephemeral to be of value in social scientific inquiry. This is particularly problematic because so much existing narrative research is cross-sectional in nature leading to reasonable questions about "which comes first?" changes in the narrative or changes in patterns of behavior (LeBel, Bushway, Maruna and Burnett, 2008). If a person's story is always changing, capturing the person's actual self-narrative at the precise moment of a particular action (e.g., a particular criminal act) is likely a futile task (Doekhie \& Van Ginneken, 2020), 
and post-hoc stories rationalizing one's changes may or may not be the same as the stories an individual tells himself prior to initiating the behavior change (Presser \& Sandberg, 2015).

How should researchers deal with such "moving targets" then? Brookman(2015) offers three ways to overcome this challenge: First, by having different researchers interview the same individual multiple times, to determine the role and impact different interviewers have in cocreating the narrative (Presser 2004). Indeed, important advances have been made in narrative criminology, involving longitudinal qualitative analysis where individuals are interviewed across numerous occasions and situations (see e.g., Doekhie \& Van Ginneken, 2020; Farrall, Hunter, \& Sharpe, 2014; Harding et al., 2017; Leverentz, 2014; Rajah et al., 2014). Second, Brookman suggests comparing narratives that arise from a one-on-one setting to a group setting, as the latter may be more impacted by the audience, are generally less practiced and lack the more structured set-up of an individual research interview. Third, she advocates for what Sandberg and colleagues (2015) have termed "plurivocality" (p. 1196), through which different aspects, layers and complexities of the story can be highlighted in different contexts to different audiences. Although the issue of stability and reliability of narrative research is likely to remain a difficult one, enriching narrative data in this way can be understood as a process akin to data triangulation.

\section{Whose Story Is This? Issues of Co-production}

This raises a further, thorny issue about narrative "ownership": If narratives exist to be shared in a social context (Harding et al., 2017), are they not distorted in some way by the audience? In other words, are storytellers not just telling us what they think "we want to hear" rather than providing insight into the internal narrative that they actually live by? After all, narratives are not created in a vacuum -- they build on and are drawn from cultural scripts or "narrative templates" that stem from the storyteller's "narrative habitus" (Fleetwood, 2015) or social world. Kruttschnitt and Kang (2019) draw attention to the notion that, beyond a storyteller's social positions and cultural repertoires (Presser, 2016), narratives can be further shaped by institutional settings and programs (Stevens, 2012). Such subcultures can restrict the range or permissible narratives as a means of social control and reproduction of existing institutional power relations (Kruttschnitt \& Kang, 2019; Mijs, 2016).

Zhang and Dong (2019) provide a dramatic example of what Warr (2019) calls "narrative labor" in the context of Chinese prisons, where prisoners have to produce a written autobiographical essay as part of the admissions process. If the essay does not conform to the prison's thematic and structural requirements, the essays are rejected and revised until the author can produce just the right penitent account in a process framed as rehabilitative.

Indeed, even in less extreme circumstances, institutions can subtly impose or delimit narrative possibilities through organizational logics and bureaucratic conventions (see Polletta et al., 2011). Such research obviously throws into question the authenticity of a 'redemptive script' produced in such circumstances, as one of the lifers in Warr's (2019) study, pointed out: "It doesn't matter whether any change is real, what matters is if it is seen, and crucially, written down. For it to be real here [in the prison] it has to be in a report" (p. $13)$.

Indeed, contemporary work in narrative criminology increasingly recognizes narrative as a co-production of both the storyteller and the audience (Mullins \& Kirkwood, 2020; Presser \& Sandberg 2015; Wesely 2018). In analyzing narratives, scholars thus call for reflexivity and disclosure of how the narratives were obtained (Presser \& Sandberg, 2015). What was the 
setting in which the narrative was delivered? In an interview situation, how did the interviewer identify herself and how did she contribute to the conversation (see Wesely 2018)? As Presser \& Sandberg (2015) point out, when presenting research results, narrative researchers should also tell the story of the research itself. Dollinger (2018) has taken this further, building narrative context into the data analysis process using a method called Membership Categorization Analysis (MCA). By analyzing positions and categorizations of parts of the story, this tool allows the researcher to understand how cultural discourses on crime are structured and function. In considering the context in which narratives are presented, MCA bridges the gap between (macro) discourses and local (micro) stories. Such analyses shed light on the "narrative positioning" (p. 481) of the story, and from there to broader cultural discourses (Dollinger, 2018).

\section{“Talk is Cheap”: Are Narratives Just Post-Hoc Rationalizations?}

One of the most prominent and persistent, if puzzling, critiques of narrative criminology involves the "distrust of the factual accuracy of any story the offender would provide" ( $p$. 392). Indeed, two of the pioneering figures in qualitative criminology research, Robert Sampson and John Laub (see e.g., Sampson \& Laub, 1993; Laub \& Sampson, 2003) have recently turned their backs on narrative pursuits for essentially this reason:

One strand of research has focused on using narratives to try and get inside the minds of offenders in order to theorize human "agency" and "identity." Although we have gone down this analytic road in considerable depth (e.g., Laub and Sampson, 2003)... we now worry that this move may have been a distraction rather than a theoretical advance. Watershed changes in cognitive science and behavioral economics have made it clear that articulated motives and self-reported reasons for action are rife with ambiguity. ... Methodologically, the implications of cognitive distortion are profound for much of the recent narrative- and interview-based research employed in criminology, including our own. As Jerolmack and Khan (2014) crisply put it, and as Goffman (1956) would no doubt endorse, "talk is cheap" when it comes to inferring causal mechanisms. ... [W] hile interesting and often fruitful in the inductive discovery of possible mechanisms, offender-given reasons for committing crime (or stopping crime) are not in themselves dispositive. If they were, we would not need criminologists (Sampson \& Laub, 2016, p. 329).

Of course, narrative criminology shares precisely this skepticism about human beings' ability to understand and articulate what they do or why they do it (see Sandberg, 2010;

Wickramagamage \& Miller, 2019). Indeed, the whole point of the narrative approach since its origins in works by authors such as Cressey (1953) and Sykes and Matza (1957) is not to accept post-hoc rationalizations at face value as "facts," but rather to query what these rationalizations $d o$ for the narrator. Toward the end of his career, in an interview with John Laub, Cressey explained this argument extremely eloquently: "Listening to people tell you why they did it does not give you explanations of why they did it. When you ask people why they commit crime, they make sounds. I call them verbalizations. These are data. You study them" (Laub, 1983, p 139, emphasis added).

Life stories are based on biographical facts, but "they go considerably beyond the facts as people selectively appropriate aspects of their experience and imaginatively construe both past and future to construct stories that make sense to them and to their audiences, that vivify and integrate life and make it more or less meaningful" (McAdams, 2001, p. 101). For 
narrative criminology, Presser \& Sandberg (2015) argue, this subjective (even partially fictive) character of a person's narrative is not just unproblematic, it is very much the point. The fact that stories serve strategic purposes (including ego management or self-presentation) is what makes them powerful (Haraway, 1997). Narrative criminology is not at all troubled about validating the accuracy of the narrator's claims, nor discerning historical "truth" (Bruner, 1987; Sandberg, 2010). Presser (2013) argues, narratives should be regarded as creating lived experience, as much as lived experience creates narratives (see also Sarbin, 1986). In other words, narrative criminology agrees with Sampson and Laub that selfnarratives are not dispositive or scientifically accurate renderings of lived reality. Yet, if reality itself is essentially "narratively structured," as Presser (2013) argues, then such "talk" hardly seems "cheap."

\section{Do Narratives Do Anything? The 'Causality' Question}

Finally, a related issue plaguing narrative research is the question of causality. Narrative criminologists tend to walk a fine line when it comes to the causal question. Note for instance that the definitions of narrative criminology above do not specifically mention the term "cause" but imply a relationship not dissimilar to a causal one. Presser and Sandberg (2019, p. 131) write that narrative criminologists study "the types, textual composition and mechanics of stories that influence -- either promote or curb -- harm-doing" (emphasis added). This is understandable. On the one hand, arguing that actions like criminal behavior were "caused" by a person's underlying self-narrative is largely circular and nonsensical (see Harding et al., 2017) -- although no more so than arguing that crime is "caused" by low selfcontrol or by having an antisocial personality disorder. On the other hand, in a positivist field of study like criminology, any research that is not in the business of explaining cause and effect is likely to be widely ignored. That is, stories are only of interest to many if they can be shown to "do" something - if telling story X leads to behavior Y in some predictable way, as in the premise behind neutralization theory (but see Matza, 1964; Maruna \& Copes, 2005).

Still, most works of narrative criminology have eschewed the need for linear causation. Harding and colleagues (2017) describe Maruna (2001) as making "strong claims about the causal effect of characteristics of narratives on desistance," yet Maruna (2001, p. 42) actually writes:

[Q]uestions may be raised as to "which comes first?" Do changes in a person's selfnarrative occur causally prior to desistance from crime or does desisting from crime simply lead someone to change their identity story? Probably both. ... Desistance is best understood using a model of co-determinacy, whereby cause and outcome are not conceived as discrete entities, but are "interrelated and overlapping, such that some part of cause is constituted by some part of the event produced in part by it and vice versa; but all of the event is not all of the cause (and vice versa)" (Henry \& Milovanovic, 1996, p. 126).

Future narrative research will require a similar level of neutrality on this question of causation. Narratives can support and help to sustain patterns of behavior but they cannot on their own cause or explain them. At the same time, scholars have warned that narrative criminologists should avoid some of the epistemological "bear traps" (Aspden \& Hayward, 2015) that narrativists in other disciplines have been caught in. In particular, Aspden \& Hayward argue, narrative criminologists have to ensure that narrative criminology "does not deteriorate into a post-structural language game concerned only with stories about reality and 
not reality itself' (2015; p. 245). That is, although the focus on narrative criminology is rightly on storytelling, ultimately the goal should be to understand actual lives and not just analyze stories for stories' sake.

\section{The Moral of the Story}

Narrative criminologists have wrestled with each of the challenges above and have confident answers for addressing each. For others outside the subfield, however, the sheer accumulation of concerns across all five of these core domains - imprecise measurement, narrative instability, the influence of social factors, unreliability of testimony, and lack of causality may be enough to dismiss or avoid the research entirely. This would be a great shame. Numerous observers have argued that criminology as a field is at risk of "sinking into a set of cliques where criminologists read the work of others who think like them, write for those very same people and publish only in the journals that they and their colleagues are already reading" (Bosworth and Hoyle, 2011: 3). Unfortunately, narrative criminology risks becoming such a clique, thriving internally, but receiving little or no notice from nor having any real engagement with the wider field of criminology - to the detriment of both.

Certainly, these challenges suggest that an embrace of narrative criminology requires a fairly radical break with mainstream criminology and its core assumptions (see Katz, 1988). Yet, other fields have been better prepared to wrestle with these challenges to core methodological assumptions. Even leading economists have recently joined in the call for shifting the focus of their field to narratives as opposed to traditional economic modeling. In their new book Radical Uncertainty: Decision-Making Beyond the Numbers, the economists John Kay and Mervyn King, former governor of the Bank of England, argue that much economic advice is "bogus quantification" and argue that the focus on statistical risk prediction should largely be replaced by a focus on "robust narratives" developed through competition between different stories. The wider field of mainstream criminology should likewise embrace a dialogue with the narrative concept.

Equally, as narrative criminology matures and takes shape as a field of inquiry, this work should seek to avoid the pitfalls of earlier qualitative research, including in the tradition of neutralization theory (see Maruna \& Copes, 2005). For instance, one of the limitations of qualitative research more generally is that the focus on discovery leads to an excess of exploratory research among ever more unusual groups (e.g., seeking to be the "first ever study of neutralizations" amongst some obscure, undiscovered category of deviance) rather than the accumulation of knowledge through replication and theory development. In addition to highlighting the predictable differences in story patterns of different groups with different backgrounds or circumstances, narrative research should also seek to establish generalities across diverse research samples in the hopes of establishing predictable relationships between narratives and action. For instance, the historian Ruth Ben-Ghiat has found distinct rhetorical consistencies between the narratives employed by right-wing authoritarian dictators across the world over a span of 100 years that can help to understand the appeal of the Donald Trump's speeches (Blitzer, 2017). Similar generalities and cross-cutting patterns may be discernible across countries and historical epochs among, for example, media reporting during moral panics about youth crime; prison or police officers who are particularly strong or weak in terms of procedural justice; or those involved in serious organised criminality. 
Finally, this work needs to link to fields outside of criminology as well. Presser (2018) has advocated for a narrative criminology that transcends issues of crime and criminal justice, and focuses on a broader definition of harm, including state and corporate actions that destroy the environment or negatively impact human development. This expansion is particularly welcome because it will necessitate a reintegration of narrative criminology with narrative research taking place in other fields (as sociologists, psychologists and other social scientists are also interested in harm, power, and corruption). To be sustainable, narrative criminology needs to become better connected to this wider work in related fields, developing the theoretical strands developed here and contributing its own to these broader conversations. Narrative criminology is already highly literate in disciplines ranging from philosophy to anthropology, but the test of the field's viability will be when these other fields start reading and recognizing narrative criminology and all that this work has to contribute.

\section{References}

Albertson, K., 2015. Creativity, self-exploration and change: creative arts-based activities' contribution to desistance narratives. The Howard Journal of Criminal Justice, 54(3), pp.277291.

Appleton, C., 2010. Life after life imprisonment. Oxford University Press.

Aresti, A., Eatough, V. and Brooks-Gordon, B., 2010. Doing time after time: an Interpretative Phenomenological Analysis of reformed ex-prisoners' experiences of self-change, identity and career opportunities. Psychology, Crime \& Law, 16(3), pp.169-190.

Aspden, K. and Hayward, K.J., 2015. Narrative criminology and cultural criminology: Shared biographies, different lives? In Narrative Criminology: Understanding Stories of Crime (pp. pp.174-203). New York: NYU Press.

Avdi, E. and Georgaca, E., 2007. Narrative research in psychotherapy: A critical review. Psychology and psychotherapy: theory, research and practice, 80(3), pp.407-419.

Bachman, R., Kerrison, E., Paternoster, R., O'Connell, D. and Smith, L., 2016. Desistance for a long-term drug-involved sample of adult offenders: The importance of identity transformation. Criminal Justice and Behavior, 43(2), pp.164-186.

Bader, E.J., 2015. Formerly Incarcerated Activist Leads Organization to Mobilize Hearts and Minds for Decarceration, available at https://truthout.org/articles/formerly-incarceratedactivist-leads-organization-to-mobilize-hearts-and-minds-for-decarceration/ (accessed 29 February 2020)

Barr, Ú., 2019. Desisting Sisters. Springer International Publishing.

Bennett, J., 1981. Oral history and delinquency: The rhetoric of criminology. Chicago, IL: The University of Chicago Press.

Bereswill, M., 2007. Fighting like a wildcat: A deep hermeneutic interpretation of The JackRoller. Theoretical Criminology, 11(4), pp.469-484. 
Best, D., Irving, J. and Albertson, K., 2017. Recovery and desistance: what the emerging recovery movement in the alcohol and drug area can learn from models of desistance from offending. Addiction Research \& Theory, 25(1), pp.1-10.

Biernacki, P., 1986. Pathways from heroin addiction: Recovery without treatment. Philadelphia: Temple University Press.

Blagden, N., Winder, B. and Lievesley, R., 2020. 'The resurrection after the old has gone and the new has come': understanding narratives of forgiveness, redemption and resurrection in Christian individuals serving time in custody for a sexual offence. Psychology, Crime \& Law, 26(1), pp.34-52.

Blitzer, J. 2016. "A Scholar of Fascism Sees a Lot That's Familiar with Trump.” New Yorker, November 4. http://www.newyorker.com/culture/culture-desk/a-scholar-of-fascismsees-a-lot-thats-familiar-with-trump. Accessed February 29, 2020

Bosworth, M. and Hoyle C., 2011. What is criminology? An introduction. In: Bosworth M and Hoyle C (eds) What Is Criminology? Oxford: Oxford University Press, pp. 1-12.

Brookman, F., 2015. The shifting narratives of violent offenders. Narrative criminology: Understanding stories of crime, pp. 207-234.

Bruner, J.S. (1986) Actual Minds, Possible Worlds, Cambridge, MA: Harvard University Press.

Bruner, J. (1987) 'Life as narrative', Social Research, 54: 11-32.

Bullock, K., Bunce, A. and McCarthy, D., 2019. Making good in unpromising places: The development and cultivation of redemption scripts among long-term prisoners. International journal of offender therapy and comparative criminology, 63(3), pp.406-423.

Canter, D. and Youngs, D., 2015. The LAAF procedure for exploring offenders' narratives. The Howard Journal of Criminal Justice, 54(3), pp. 219-236.

Carr, D. 1991. Ricoeur on narrative. In Wood. D. (ed) On Paul Ricoeur: Narrative and Interpretation. London: Routledge.

Carrabine, E., 2019. Reading Pictures: Piranesi and Carceral Landscapes. (pp. 197-216) in Fleetwood, J., Presser, L., Sandberg, S. and Ugelvik, T. eds.,The Emerald Handbook of Narrative Criminology. Bingly, UK: Emerald Group Publishing.

Cid, J. and Martí, J. (2016) Structural context and pathways of desistance. Research in Spain. In: Shapland J, Farrall S and Bottoms A (eds) Global Perspectives on Desistance. London: Routledge, pp. 66-82.

Cohen, S., 1972. Folk devils and moral panics: The creation of the mods and rockers. London: MacGibbon \& Kee.

Colvin, S., 2015. Why should criminology care about literary fiction? Literature, life narratives and telling untellable stories. Punishment \& Society, 17(2), pp.211-229. 
Copeland, S., 2019. Telling stories of terrorism: a framework for applying narrative approaches to the study of militant's self-accounts. Behavioral sciences of terrorism and political aggression, 11(3), pp. 232-253.

Copes, H., Hochstetler, A. \& Ragland, J. 2019., The stories in images: The value of the visual for narrative criminology (pp. 175 - 196) in Fleetwood, J., Presser, L., Sandberg, S. and Ugelvik, T. eds.,The Emerald Handbook of Narrative Criminology. Bingly, UK: Emerald Group Publishing.

Cressey, D. R., 1953. Other people's money: A study in the social psychology of embezzlement. Glencoe, IL: Free Press.

Cressey, D. R. 1963., Social psychological theory for using deviants to control deviation. In Experiment in culture expansion: Proceedings of the conference on "The Use of Products of a Social Problem in Coping With the Problem Norco, CA” (pp. 147-160). Washington, DC: National Institute of Mental Health.

Crewe, B. and Maruna, S. 2006., Life Narratives and Fieldwork Methodology (pp. 109-123) in D. Hobbs and R. Wright (Eds.) The Handbook of Fieldwork. London: Sage.

Cromwell, P., 1996. In Their Own Words: Criminals on Crime. Boston: Roxbury Publishing.

Denver, M. and Ewald, A., 2018. Credentialing decisions and criminal records: A narrative approach. Criminology, 56(4), pp.715-749.

DeValiant, G., McGrath, L. and Kougiali, Z., 2020. Through the prison walls: Using published poetry to explore current UK prisoners' narratives of past, present and future selves. Qualitative Research in Psychology, 17(2), pp.240-257.

Divall, B., 2015. Negotiating competing discourses in narratives of midwifery leadership in the English NHS. Midwifery, 31(11), pp.1060-1066.

Doekhie, J. and Van Ginneken, E., 2020. House, bells and bliss? A longitudinal analysis of conventional aspirations and the process of desistance. European Journal of Criminology, 1477370818819702.

Dollinger, B., 2018. Subjects in criminality discourse: On the narrative positioning of young defendants. Punishment \& Society, 20(4), pp. 477-497.

Elliott, R. and Wattanasuwan, K., 1998. Brands as symbolic resources for the construction of identity. International journal of Advertising, 17(2), pp. 131-144.

Ermann, L.S., Lawson, G. and Burge, P.L., 2017. The intersection of narrative therapy and AA through the eyes of older women. The International Journal of Reminiscence and Life Review, 4(1), pp. 14-23.

Fader, J.J. and Traylor, L.L., 2015. Dealing with difference in desistance theory: The promise of intersectionality for new avenues of inquiry. Sociology Compass, 9(4), pp.247-260.

Farrall, S., Hunter, B. and Sharpe, G., 2014. Criminal careers in transition: The social context of desistance from crime. Oxford University Press. 
Fiese, B.H. and Spagnola, M., 2005. Narratives in and about families: an examination of coding schemes and a guide for family researchers. Journal of Family Psychology, 19(1), pp. 51-61.

Finestone, H. (1976) Victims of Change: Juvenile Delinquents in American Society. Westport, CT: Greenwood Press.

Fleetwood, J., 2015. A narrative approach to women's lawbreaking. Feminist Criminology, 10(4), pp.368-388.

Fleetwood, J., Presser, L., Sandberg, S. and Ugelvik, T. eds., 2019. The Emerald Handbook of Narrative Criminology. Bingly, UK: Emerald Group Publishing.

Flores, E.O., 2016. "Grow your hair out": Chicano gang masculinity and embodiment in recovery. Social Problems, 63(4), pp.590-604.

Foucault, M., 1972. The Archeology of Knowledge, trans. A. M. Sheridan Smith. London: Tavistock.

Fox, K.J., 1999. Changing violent minds: Discursive correction and resistance in the cognitive treatment of violent offenders in prison. Social Problems, 46(1), pp.88-103.

Gadd, D. and Jefferson, T., 2007. On the defensive: A psychoanalytically informed psychosocial reading of The Jack-Roller. Theoretical Criminology, 11(4), pp.443-467.

Geertz, C., 1973. The interpretation of cultures. New York: Basic Books.

Gelsthorpe, L., 2007. The Jack-Roller: telling a story?. Theoretical Criminology, 11(4), pp.515-542.

Gergen, K.J. and Gergen, M.M., 1988. Narrative and the self as relationship. In Advances in experimental social psychology (Vol. 21, pp. 17-56). Academic Press.

Giddens, A., 1991. Modernity and self-identity: Self and society in the late modern age. Stanford university press.

Giordano, P.C., Cernkovich, S.A. and Rudolph, J.L., 2002. Gender, crime, and desistance: Toward a theory of cognitive transformation. American journal of sociology, 107(4), pp.9901064.

Giordano, P.C., Johnson, W.L., Manning, W.D., Longmore, M.A. and Minter, M.D., 2015. Intimate partner violence in young adulthood: Narratives of persistence and desistance. Criminology, 53(3), pp.330-365.

Gottschall, J., 2012. The storytelling animal: How stories make us human. Houghton Mifflin Harcourt.

Hallett, M. and McCoy, J.S., 2015. Religiously motivated desistance: An exploratory study. International Journal of Offender Therapy and Comparative Criminology, 59(8), pp.855-872. 
Hanninen, V., \& Koski-Jannes, A. (1999). Narratives of recovery from addictive behaviours. Addiction, 94(12), 1837-1848.

Haraway, D., 1997.Modest_Witness@Second_Millennium.FemaleMan_Meets_OncoMouse: feminism and technoscience. Routledge.

Harding, D.J., Dobson, C.C., Wyse, J.J. and Morenoff, J.D., 2017. Narrative change, narrative stability, and structural constraint: The case of prisoner reentry narratives. American journal of cultural sociology, 5(1-2), pp.261-304.

Harris, D.A., 2014. Desistance from sexual offending: Findings from 21 life history narratives. Journal of interpersonal violence, 29(9), pp.1554-1578.

Hart, W. and Healy, D., 2018. 'An inside job': An autobiographical account of desistance. European Journal of Probation, 10(2), pp.103-119.

Henry, Stuart, and Dragan Milovanovic. 1996. Constitutive Criminology. Thousand Oaks, Calif.: Sage.

Herbert, S., 2018. Inside or outside? Expanding the narratives about life-sentenced prisoners. Punishment \& Society, 20(5), pp.628-645.

Holstein, J.A. and Gubrium, J.F., 2000. The self we live by: Narrative identity in a postmodern world. New York: Oxford University Press.

Hourigan, K.L., 2019. Narrative Victimology: Speaker, Audience, Timing. (pp. 259 - 277). in Fleetwood, J., Presser, L., Sandberg, S. and Ugelvik, T. eds.,The Emerald Handbook of Narrative Criminology. Bingly, UK: Emerald Group Publishing.

Ievins, A., 2019. Finding victims in the narratives of men imprisoned for sex offences. (pp. 279 - 302) in Fleetwood, J., Presser, L., Sandberg, S. and Ugelvik, T. eds.,The Emerald Handbook of Narrative Criminology. Bingly, UK: Emerald Group Publishing.

Kang, T., Kruttschnitt, C. and Goodman, P., 2017. Multi-Method Synergy: Using the Life History Calendar and Life as a Film for Retrospective Narratives. The Howard Journal of Crime and Justice, 56(4), pp. 532-553.

Katz, J., 1988 . Seductions of crime: Moral and sensual attractions in doing evil. New York: Basic Books.

Katz, N.H., Bascombe, N.G. and Tokar, P., 2019. Illuminating interviews: Insights into the hearts and minds of conflict resolution practitioners. Conflict Resolution Quarterly, 36(4), pp.345-371.

Kay, J.A. and King, M.A., 2020. Radical Uncertainty: Decision-making Beyond the Numbers. WW Norton.

Kay, C. and Monaghan, M., 2019. Rethinking recovery and desistance processes: developing a social identity model of transition. Addiction Research \& Theory, 27(1), pp.47-54. 
King, S., 2013. Early desistance narratives: A qualitative analysis of probationers' transitions towards desistance. Punishment \& Society, 15(2), pp.147-165.

Kirkwood, S., 2016. Desistance in action: An interactional approach to criminal justice practice and desistance from offending. Theoretical Criminology, 20(2), pp.220-237.

Koesling, A. and Neuber, A., 2007. Thehome-sickness' of The Jack-Roller. Theoretical Criminology, 11(4), pp. 501-513.

Kotre, J. 1984. Outliving the self: How we live on in future generations. Baltimore: John Hopkins University Press.

Kruttschnitt, C. and Kang, T., 2019. Do intersectional variations shape prisoners' understanding of their past lives? An examination of the stock narratives of persistent offenders. Justice Quarterly, pp. 1-28.

Laird, J. 1989. Women and stories. In M. McGoldrick, C. Anderson, \& F. Walsh (Eds.), Women in families: A frameworkfor family therapy (pp. 428-449). New York: W. W. Norton.

Laub, J., 1983. Criminology in the Making: An Oral History. Boston: Northeastern.

Laub \& Sampson, 2003. Shared beginnings, divergent lives: Delinquent boys to age 70. Cambridge, MA: Harvard University Press.

Lawless, E.J., 2001. Women escaping violence: Empowerment through narrative. University of Missouri Press.

LeBel, T.P., Burnett, R., Maruna, S. and Bushway, S., 2008. Thechicken and egg'of subjective and social factors in desistance from crime. European Journal of Criminology, 5(2), pp.131-159.

Leverentz, A. M. (2014). The ex-prisoner's dilemma: how women negotiate competing narratives of reentry and desistance. Rutgers University Press.

Liem, M., 2016. After life imprisonment: reentry in the era of mass incarceration. New York: NYU Press.

Liem, M. 2017. Desistance after life imprisonment. In New perspectives on desistance (pp. 85-108). London: Palgrave Macmillan.

Liem, M. and Richardson, N.J., 2014. The role of transformation narratives in desistance among released lifers. Criminal Justice and Behavior, 41(6), pp. 692-712.

Loseke, D.R., 2007. The study of identity as cultural, institutional, organizational, and personal narratives: Theoretical and empirical integrations. The Sociological Quarterly, 48(4), pp.661-688.

Maines, D.R., 1993. Narrative's moment and sociology's phenomena: Toward a narrative sociology. The Sociological Quarterly, 34(1), pp.17-38. 
Maruna, S., 1997. Going Straight: Desistance from Crime and Self-Narratives of Reform. Narrative Study of Lives, 5, 59-97.

Maruna, S., 2001. Making good: How ex-convicts reform and rebuild their lives. Washington, DC: American Psychological Association Books.

Maruna, S., 2004. Desistance and Explanatory Style: A New Direction in the Psychology of Reform. Journal of Contemporary Criminal Justice, 20, 184-200.

Maruna, S., \& Copes, H., 2005. What have we learned in five decades of neutralization research? Crime and Justice: A Review of Research, 32, pp. 221-320.

Maruna, S. and Matravers, A., 2007. N= 1: Criminology and the person. Theoretical Criminology, 11(4), pp.427-442.

Maruna, \& Pali, B. 2020, forthcoming. From Victim Blaming to Reintegrative Shaming: The Continuing Relevance of Crime, Shame and Reintegration in the Era of \#MeToo.

International Journal of Restorative Justice

McAdams, D.P., 1993. The stories we live by: Personal myths and the making of the self. Guilford Press.

McAdams, D.P., 2001. The psychology of life stories. Review of general psychology, 5(2), pp.100-122.

McAdams, D.P. and McLean, K.C., 2013. Narrative identity. Current directions in psychological science, 22(3), pp. 233-238.

McNay, L., 1999. Gender and narrative identity. Journal of Political Ideologies, 4(3), pp. 315-336.

Meyer, A., 2010. Evil monsters and cunning perverts: Representing and regulating the dangerous paedophile. Popular culture, crime and social control, 14, pp.195-217.

Meyer, S., 2016. Still blaming the victim of intimate partner violence? Women's narratives of victim desistance and redemption when seeking support. Theoretical Criminology, 20(1), pp.75-90.

Merton, R.K. (1938). Social structure and anomie. American Sociological Review, 3, pp. $672-682$.

Messner, S.F. and Rosenfeld, R., 2012. Crime and the American dream. Cengage Learning.

Michalowski, R.J., 2016. What is crime?. Critical Criminology, 24(2), pp.181-199.

Mijs, J.J., 2016, June. The missing organizational dimension of prisoner reentry: An ethnography of the road to reentry at a nonprofit service provider. In Sociological Forum (Vol. 31, No. 2, pp. 291-309). 
Mullins, E. and Kirkwood, S., 2020. Co-authoring desistance narratives: Analysing interactions in groupwork for addressing sexual offending. Criminology \& Criminal Justice, p.1748895819863101.

O'Reilly, E.B., 1997. Sobering tales: Narratives of alcoholism and recovery. Univ of Massachusetts Press. O’Sullivan, Kemp \& Bright 2015

Österman, L., 2017. Penal cultures and female desistance. London: Routledge.

O'Sullivan, K., Kemp, R. and Bright, D., 2015. Identity, self-story and desistance from crime. Journal of Forensic Practice, 17, 219-230.

Paternoster, R. and Bushway, S., 2009. Desistance and the" feared self": Toward an identity theory of criminal desistance. The Journal of Criminal Law and Criminology, pp.1103-1156.

Pelikan, C. and Hofinger, V., 2016. An interactional approach to desistance: expanding desistance theory based on the Austrian mediation practice in cases of partnership violence. Restorative Justice, 4(3), pp.323-344.

Pemberton, A. and Aarten, P.G., 2018. Narrative in the study of victimological processes in terrorism and political violence: An initial exploration. Studies in Conflict \& Terrorism, 41(7), pp. 541-556.

Pemberton, A., Aarten, P. G. M., \& Mulder, E., 2019. Stories as property: Narrative ownership as a key concept in victims' experiences with criminal justice. Criminology and Criminal Justice, 19(4), pp. 404-420.

Pemberton, A., Mulder, E., \& Aarten, P. G., 2019. Stories of injustice: Towards a narrative victimology. European Journal of criminology, 16(4), pp. 391-412.

Peterson, C., Schulman, P., Castellon, C. and Seligman, M.E.P., 1992. CAVE: Content analysis of verbatim explanations. (pp.383-392). Motivation and personality: Handbook of thematic content analysis, edited by Charles P. Smith. New York: Cambridge University Press.

Polletta, F., Chen, P.C.B., Gardner, B.G. and Motes, A., 2011. The sociology of storytelling. Annual Review of Sociology, 37, pp.109-130.

Presser, L., 2004. Violent offenders, moral selves: Constructing identities and accounts in the research interview. Social problems, 51(1), pp.82-101.

Presser, L., 2009. The narratives of offenders. Theoretical Criminology, 13(2), pp. 177-200.

Presser, L., 2010. Been a heavy life: Stories of violent men. University of Illinois Press.

Presser, L., 2012. Getting on top through mass murder: Narrative, metaphor, and violence. Crime, Media, Culture, 8(1), pp. 3-21.

Presser, L., 2013. Why we harm. New Brunswick, NJ: Rutgers University Press.

Presser, L., 2016. Criminology and the Narrative Turn. Crime Media Culture, 12(2), pp. 137151. 
Presser, L., 2018. Inside story: How narratives drive mass harm. Berkeley, CA: University of California Press.

Presser, L., and Sandberg, S., 2015. Narrative criminology: Understanding stories of crime. New York: NYU Press.

Presser, L., and Sandberg, S., 2019. Narrative criminology as critical criminology. Critical criminology, 27(1), pp. 131-143.

Presser, L. and Sandberg, S., 2015. Research Strategies for Narrative Criminology. In Qualitative Research in Criminology (pp. 85 - 99) Taylor \& Francis.

Rajah, V., Kramer, R. and Sung, H.E., 2014. Changing narrative accounts: How young men tell different stories when arrested, enduring jail time and navigating community reentry. Punishment \& Society, 16(3), pp.285-304.

Redl, F., \& Wineman, D., 1951. Children who hate: The disorganization and breakdown of behavior controls. Glencoe, IL: Free Press.

Ricoeur, P., 1994. Oneself as another. University of Chicago Press.

Robinson-Edwards, S. and Pinkney, C., 2018. Black men, religiosity and desistance: Exploring Islam, desistance and identity. Safer Communities.

Rocque, M. (2017). Desistance from crime: New advances in theory and research. Springer.

Rudrum, D., 2006. On the very idea of a definition of narrative: A reply to Marie-Laure Ryan. Narrative, 14(2), pp.197-204.

Saleebey, D., 1994. Culture, theory, and narrative: The intersection of meanings in practice. Social work, 39(4), pp.351-359.

Sampson, R. J., and Laub, J. H., 1993. Crime in the making: Pathways and turning points through life. Cambridge, MA: Harvard University Press.

Sampson, R.J. and Laub, J.H., 2016. Turning points and the future of life-course criminology: reflections on the 1986 criminal careers report. Journal of Research in Crime and Delinquency, 53(3), pp. 321-335.

Sandberg, S., 2016. The importance of stories untold: Life-story, event-story and trope. Crime, Media, Culture, 12(2), pp.153-171.

Sandberg, S., 2010. What can 'lies' tell us about life? Notes towards a framework of narrative criminology. Journal of Criminal Justice Education, 21(4), pp. 447-465.

Sandberg, S., Tutenges, S. and Copes, H., 2015. Stories of violence: A narrative criminological study of ambiguity. British Journal of Criminology, 55(6), pp.1168-1186.

Sandberg, S., \& Ugelvik, T., 2016. The past, present, and future of narrative criminology: A review and an invitation. Crime, Media and Culture, 21(2), pp. 129-136. 
Sarbin, T.R., 1986, Narrative Psychology: The Storied Nature of Human Conduct, New York: Praeger.

Sartre, J-P., 1938/1965. Nausea (Translated by Robert Baldick). Harmandsworth: Penguin.

Scott, M. B., \& Lyman, S. M., 1968. Accounts. American Sociological Review, 33, pp. 4662.

Sharpe, G., 2015. Precarious identities:'Young'motherhood, desistance and stigma. Criminology \& Criminal Justice, 15(4), pp.407-422.

Shaw C.R., 1930. The Jack Roller. A delinquent boy's own story. Chicago: University of Chicago.

Singer, J. A., 1997. Message in a bottle: Stories of men and addiction. New York: Free Press.

Somers, M.R., 1994. The narrative constitution of identity: A relational and network approach. Theory and society, pp. 605-649.

Soyer, M., 2014. The imagination of desistance: A juxtaposition of the construction of incarceration as a turning point and the reality of recidivism. British Journal of Criminology, 54(1), pp.91-108.

Søgaard, T.F., Kolind, T., Thylstrup, B. and Deuchar, R., 2016. Desistance and the micronarrative construction of reformed masculinities in a Danish rehabilitation centre. Criminology \& Criminal Justice, 16(1), pp.99-118.

Sparks, R., 1992. Television and the drama of crime: Moral tales and the place of crime in public life. Milton Keynes, UK: Open University Press.

Stevens, A., 2012. 'I am the person now I was always meant to be': Identity reconstruction and narrative reframing in therapeutic community prisons. Criminology \& Criminal Justice, 12(5), pp. 527-547.

Sternberg, R.J., 1998. Cupid's arrow: The course of love through time. New York: Cambridge University Press.

Stone, R., 2016. Desistance and identity repair: Redemption narratives as resistance to stigma. British Journal of Criminology, 56(5), pp.956-975.

Stone, R., 2019. "God, I Don't Want that Woman to Be Right about Me": Memorable Messages, Reflected Appraisals, and Women's Desistance. Victims \& Offenders, 14(6), pp.671-691.

Stone, R., Morash, M., Goodson, M., Smith, S. and Cobbina, J., 2018. Women on parole, identity processes, and primary desistance. Feminist Criminology, 13(4), pp.382-403.

Sundt, J., 2010. Redemption Scripts and Desistance. In Cullen, F.T. and Wilcox, P. eds., 2010. Encyclopedia of criminological theory (Vol. 1). Sage.

Sutherland, E. H., 1937. The professional thief. Chicago: University of Chicago. 
Sykes, G. M., \& Matza, D., 1957. Techniques of neutralisation: A theory of delinquency. American Sociological Review, 22, pp. 664-673.

Taylor, C., 1989. Sources of the self: The making of the modern identity. Harvard University Press.

Thomas, W.I. \& Thomas, D.S., 1928. The child in America: Behavior problems and programs. New York: Knopf.

Van der Heide, E.J. and Huurman, R., 2016. Suburban bliss or disillusionment: why do terrorists quit?. Journal for Radicalization, pp. 1 - 24.

Vaughan, B., 2007. The internal narrative of desistance. The British Journal of Criminology, 47(3), pp.390-404.

Veysey, B.M., Martinez, D.J. and Christian, J., 2013. "Getting Out:” A Summary of Qualitative Research on Desistance Across the Life Course. In Handbook of life-course criminology (pp. 233-260). Springer, New York, NY.

Walklate, S., Maher, J., McCulloch, J., Fitz-Gibbon, K. and Beavis, K., 2019. Victim stories and victim policy: Is there a case for a narrative victimology?. Crime, media, culture, 15(2), pp. 199-215.

Warr, J., 2019. 'Always gotta be two mans': Lifers, risk, rehabilitation, and narrative labour. Punishment \& Society, p.1462474518822487.

Weaver, B. and McNeill, F., 2015. Lifelines: Desistance, social relations, and reciprocity. Criminal justice and behavior, 42(1), pp.95-107.

Weaver, A. and Weaver, B., 2013. Autobiography, empirical research and critical theory in desistance: A view from the inside out. Probation Journal, 60(3), pp.259-277.

Wesely, J.K., 2018. Co-constituting narrative: the role of researcher identity bids in qualitative interviews with women ex-offenders. Criminal Justice Studies, 31(3), pp.213-229.

White, M.K., 2007. Maps of narrative practice. WW Norton \& Company.

Wickramagamage, C. and Miller, J., 2019. Stories that Are Skyscraper Tall: The Place of 'Tall Tales' (pp.109 - 128) in Fleetwood, J., Presser, L., Sandberg, S. and Ugelvik, T. eds.,The Emerald Handbook of Narrative Criminology. Bingly, UK: Emerald Group Publishing.

Wilson, E. O. 2005., Forward from the Scientific Side. (pp. vii-xi). In The Literary Animal: Evolution and the Nature of Narrative, ed. J. Gottschall and D. Sloan Wilson. Evanston, IL: Northwestern University Press.

Wittebrood, K. and Nieuwbeerta, P., 2000. Criminal victimization during one's life course: The effects of previous victimization and patterns of routine activities. Journal of research in crime and delinquency, 37(1), pp.91-122.

Wright, F.A., 2014. The short story just got shorter: Hemingway, narrative, and the six-word urban legend. Journal of Popular Culture, 47(2), pp.327-340. 
Zhang, X. and Dong, X. (2019). The archived criminal: Mandatory prisoner autobiography in China (pp. 427 - 444). In Fleetwood, J., Presser, L., Sandberg, S. and Ugelvik, T. eds.,The Emerald Handbook of Narrative Criminology. Bingly, UK: Emerald Group Publishing. 